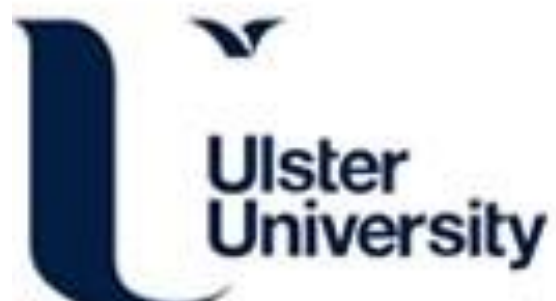

\section{Long-term belowground effects of grassland management: the key role of liming}

Heyburn, J., McKenzie, S. J. P., Crawley, M. J., \& Fornara, D. A. (2017). Long-term belowground effects of grassland management: the key role of liming. Ecological Applications, 27(7), 2001-2012.

https://doi.org/10.1002/eap.1585

Link to publication record in Ulster University Research Portal

\section{Published in:}

Ecological Applications

Publication Status:

Published (in print/issue): 02/10/2017

DOI:

10.1002/eap. 1585

\section{Document Version}

Author Accepted version

\section{General rights}

Copyright for the publications made accessible via Ulster University's Research Portal is retained by the author(s) and / or other copyright owners and it is a condition of accessing these publications that users recognise and abide by the legal requirements associated with these rights.

\section{Take down policy}

The Research Portal is Ulster University's institutional repository that provides access to Ulster's research outputs. Every effort has been made to ensure that content in the Research Portal does not infringe any person's rights, or applicable UK laws. If you discover content in the Research Portal that you believe breaches copyright or violates any law, please contact pure-support@ulster.ac.uk. 
Article type : Articles

Running Head:

Long-term belowground effects of liming

Title:

Long-term belowground effects of grassland management: the key role of liming

Authors:

Jemma Heyburn ${ }^{1}$, Paul McKenzie ${ }^{1}$, Michael J. Crawley ${ }^{2}$, Dario A. Fornara ${ }^{3, *}$

${ }^{1}$ School of Geography \& Environmental Sciences, Ulster University, Cromore Rd, BT52 1SA

Coleraine, UK

${ }^{2}$ Department of Life Sciences, Imperial College, Silwood Park, Ascot, Berkshire SL5 7PY,

UK

${ }^{3}$ Agri-Food \& Biosciences Institute (AFBI), Newforge Lane, BT9 5PX, Belfast, UK

Correspondence to:

*Dr. Dario Fornara

Sustainable Agri-Food Sciences Division

Agri-Food \& Biosciences Institute (AFBI)

Newforge Lane, BT9 5PX Belfast, UK

Tel: +44 (0)2890255335

Email: dario.fornara@afbini.gov.uk

Jemma Heyburn, email: Heyburn-J1@email.ulster.ac.uk

Paul McKenzie, email: sjp.mckenzie@ulster.ac.uk

Michael J. Crawley, email: m.crawley@imperial.ac.uk

This article has been accepted for publication and undergone full peer review but has not been through the copyediting, typesetting, pagination and proofreading process, which may lead to differences between this version and the Version of Record. Please cite this article as doi: 10.1002/eap.1585

This article is protected by copyright. All rights reserved. 


\section{Abstract}

The functioning of human-managed grassland ecosystems strongly depends on how common management practices will affect grassland 'belowground compartment' including soil biogeochemistry and plant roots. Key questions remain about how animal grazing, liming (e.g. the addition of $\mathrm{CaCO}_{3}$ to soils), and nutrient fertilization might affect, in the long-term, soil nutrient cycling and multiple root traits. Here we focus on a mesotrophic grassland located in Berkshire, UK, where contrasting levels of rabbit grazing, liming and different inorganic fertilizers have been applied since 1991. We ask how (1) soil nitrogen (N) availability and cycling, (2) total root mass, (3) root mass decomposition, and (4) arbuscular mycorrhizal fungal (AMF) root colonisation might respond to 22 years of very different management. We found that liming strongly affected total root mass, root decomposition, root AMF colonisation as well as soil $\mathrm{N}$ availability and cycling and that these effects were mainly driven by liming-induced increases in soil $\mathrm{pH}$. Increases in soil $\mathrm{pH}$ were associated with significant (1) decreases in root mass, (2) increases in root mass decomposability and in the mineralization of $\mathrm{N}$ in decomposing root detritus, and (3) increases in AMF infection. Soil $\mathrm{pH}$ was also significantly related to greater $\mathrm{N}$ availability (i.e. soil $\mathrm{NO}_{3}$ levels) and to lower $\delta^{15} \mathrm{~N}$ natural abundance, which suggests more efficient $\mathrm{N}$ uptake by plants in limed soils as we found in our study. The application of multiple nutrients (NPKMg) also reduced total root mass, while $\mathrm{N}$-only fertilization was associated with greater AMF infection.

Surprisingly the long-term impact of grazing was generally weak and not significant on most plant and soil parameters. Despite soil $\mathrm{pH}$ affecting most belowground variables, changes in soil $\mathrm{pH}$ were not associated with any change in soil $\mathrm{C}$ and $\mathrm{N}$ stocks. Because liming can improve nutrient cycling (and benefits soil $\mathrm{pH}$ and grass yields) without negatively affecting soil $\mathrm{C}$ sequestration, we suggest that regular liming applications may provide management solutions for increasing the long-term sustainability of permanent grassland. 
Key Words: carbon sequestration, ecosystem services, grassland management, grazing, nitrogen cycling, nutrient fertilization, soil $\mathrm{pH}$

\section{Introduction}

The functioning of human-managed grassland ecosystems greatly depends on the long-term effects that common management practices will have on the cycling and storage of key elements such as carbon (C), nitrogen (N) and phosphorus (P) (Conant et al. 2001, Soussana \& Lemaire 2014, Fornara et al. 2016). Common management practices include animal grazing and the application to soils of different fertilizing materials including macro-nutrients (e.g. N, P, K, Mg) and lime (e.g. $\mathrm{CaCO}_{3}$ ), all of which are known to influence grassland ecosystem functioning (Fornara et al. 2011, Isbell et al. 2013, Orwin et al. 2015, Sochorová et al. 2016). So far, a large number of research studies have focused on the relationships between management and changes in plant aboveground biomass, mainly because grassland productivity remains a key ecosystem service delivered to human society. Fewer studies have addressed potential long-term effects of different management practices (e.g. grazing, nutrient fertilisation and liming) on multiple plant belowground traits (e.g. total root mass, rates of root mass decomposition, root-microbial symbioses) in grassland ecosystems.

Changes in root traits may have important consequences for soil nutrient cycling and the sequestration of $\mathrm{C}$ and $\mathrm{N}$ in grassland soils.

From an ecosystem functioning perspective, common grassland management practices greatly contribute to increase the availability of reactive inorganic forms of $\mathrm{N}$ and $\mathrm{P}$ in soils. Because of the close coupling of $\mathrm{C}$ and $\mathrm{N}$ cycles in soil ecosystems (Christopher and Lal 2007) changes in soil $\mathrm{N}$ availability may greatly affect soil $\mathrm{C}$ storage in human-managed grasslands (Lu et al. 2011, Riggs et al. 2015). Repeated nutrient additions can also influence total root mass and root C pools (Liu and Greaver 2010, Lu et al. 2011), mainly because of 
the reduced role of roots in foraging for soil nutrients. For example, in natural or semi-natural ecosystems plant species tend to develop larger root systems, which maximise nutrient absorption especially in nutrient-poor soils (Hobbie 1992, Müller et al. 2000). Long-term repeated additions of multiple nutrients (i.e. $\mathrm{NPKMg}$ ) to soils can significantly reduce plant biomass investment to belowground compartments (Fornara et al. 2013). This in turn will affect both the quantity and quality of root plant detritus returned to soils, thus potentially influencing rates of root mass decomposition.

Root litter quality (e.g. root $\mathrm{N}$ content, root lignin content, root $\mathrm{C}: \mathrm{N}$ ratios), together with climatic factors and local soil conditions, plays a key role in regulating rates of root decomposition (Silver \& Miya 2001, Fornara et al. 2009, Solly et al. 2014, Chen et al. 2017). Most root decomposition studies, however, have been carried out in natural and semi-natural ecosystems where human impact is generally lower. Thus, it is not clear how root decomposition might respond to multiple long-term grassland management practices.

Repeated nutrient fertilisation and animal grazing can also greatly influence rootmicrobial associations, such as root colonisation by arbuscular mycorrhizal fungi (AMF; Glomeromycota) (Hodge et al. 2001). Mycorrhizal fungi form a mutualistic relationship with roots, whereby fungi can provide soil nutrients to plants in return for the $\mathrm{C}$ supplied by host plants (Bardgett 2005). AMF are very common in grasslands (Johnson et al. 2003, Chapin III et al. 2012), however, their presence and abundance can be significantly affected by longterm nutrient fertilisation (Johnson et al. 2015, Liu et al. 2015, Propster and Johnson 2015, Sochorová et al. 2016). The common use of agricultural lime (non-nutrient fertilizer), which improves soil $\mathrm{pH}$ conditions might influence root decomposition processes through liminginduced increases in soil biological activity and/or changes in microbial composition (Fornara et al. 2011). Liming applications, for example, have been associated with higher AMF colonisation of roots (Johnson et al. 2005).

This article is protected by copyright. All rights reserved. 
In this study we first address how (1) total root mass, (2) root mass decomposition, and (3) root AMF colonisation might respond to 22 years of grassland management, which include rabbit grazing, liming and chronic nutrient fertilisation. Secondly, we search for potential linkages between these root 'traits' and changes in important soil properties (i.e. soil $\mathrm{N}$ and $\mathrm{P}$ availability and total soil $\mathrm{C}, \mathrm{N}$ and $\mathrm{P}$ pools). We hypothesize that plant belowground responses to long-term management will be mainly driven by the increased availability of organic and inorganic forms of nutrients (e.g. $\mathrm{N}$ and $\mathrm{P}$ ), due to direct or indirect effects of grazing animals, artificial fertiliser and liming applications to soils.

Our study specifically tested the following hypotheses:

(1) Total root mass will decrease whilst rates of root decomposition will increase under long-term multiple nutrient (e.g. NPKMg) additions;

(2) Total root mass will decrease under grazing, partly because of increased nutrient additions to soils from grazing animals and partly because of plant aboveground responses to biomass removal by grazers (Holland et al. 1996);

(3) AMF colonisation will increase in chronically $\mathrm{N}$-fertilised soils, which have not received any inorganic $\mathrm{P}$ addition for decades thus leading to greater P-limitation for plant growth;

(4) Liming-induced increases in soil $\mathrm{pH}$ by stimulating soil $\mathrm{NO}_{3}$ availability (Kunhikrishnan et al. 2016) and microbial activity (Fornara et al. 2011) will lead to lower root mass, higher rates of root decomposition and greater AMF colonisation to acquire inorganic P from soils (Johnson et al. 2003).

We tested these hypotheses using data from a long-term grassland experiment where grazing, liming and five different nutrient treatments (i.e. Control, N-only, P-only, NPMg and $\mathrm{NPKMg}$ ) have been applied for 22 years. 


\section{Methods}

Study Site

We conducted our study at Silwood Park, Berkshire, UK, where a long-term grassland experiment (i.e. Nash's Field) was established in 1991 to test for the effects of common grassland management practices on plant species composition and plant yields (Crawley 1990; http://www.imperial.ac.uk/silwood-park/research/silwood-lte/nashk-s/). Nash's Field is a mesotrophic grassland described as Lolio-Cynosuretum cristati grassland, Anthoxanthum odoratun subcommunity according to the British National Vegetation Classification community (Rodwell 1992). This grassland is characterized by sandy, acidic soils of the Bagshot Series where introduced European rabbits (Oryctolagus cuniculus) have been particularly abundant since the 1950s. Before 1991 Nash's field was managed as a hay meadow and it is now dominated by perennial C3 grasses including Agrostis capillaris, Festuca rubra and Holcus lanatus. Common forbs include Galium saxalite and Rumex acetosella. A recent study of the Nash's Field shows how C3 grasses represent at least $73 \%$ of the total aboveground biomass in these experimental plots, whereas biomass of nonleguminous forbs varies between $10 \%$ and $16 \%$ and legume biomass represents $<0.1 \%$ of the plant community biomass (Fornara et al. 2013).

Nash's Field is organized in a 4-factor split plot design (Appendix S1: Fig. S1). The experiment includes four large blocks $(44 \times 20 \mathrm{~m}$ each), two randomly selected to receive insecticide (- insects) and two with no insecticide applied (+ insects). Within each block the split-plot design incorporates two grazing plots $(22 \times 22 \mathrm{~m}$ each $)$. Then, each grazing plot includes two liming plots $(18 \times 8 \mathrm{~m}$ each $)$, and finally each liming plot incorporates five nutrient plots $(2 \times 2 \mathrm{~m}$ each $)$. Thus, 4 blocks $\times 2$ rabbit grazing treatments $\times 2$ liming treatments $\times 5$ nutrient treatments $=80$ individual experimental units. 
The insecticide treatment includes a cocktail of knock-down (Ambush, permethrin synthetic pyrethroid at $150 \mathrm{~g}$ a.i. ha ${ }^{-1}$ ); Amvac Chemical, Surrey, UK) and systemic (Dimethoate-40; applied at $350 \mathrm{~g}$ a.i. ha $^{-1}$; BASF, Cheadle, UK) insecticides, which has been applied on three occasions each year (i.e. April, July, September) since 1992 (see also Allan and Crawley 2011). Rabbits were excluded from 1991, using fences constructed of wire mesh ( $3 \mathrm{~cm}$ diameter mesh size) attached to a rigid top wire, supported by wooden posts every 3.5

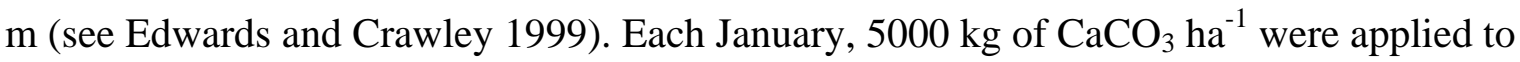
the limed plots. Each of the 80 small experimental plots $\left(4 \mathrm{~m}^{2}\right)$ has been managed to receive specific combinations of nutrient fertilisers (Crawley 1990). In this study, we specifically focused on the following 5 nutrient-treatments: (1) N-only, (2) P-only, (3) $\mathrm{N}+\mathrm{P}+\mathrm{Mg}$, (4) all nutrients $(\mathrm{N}+\mathrm{P}+\mathrm{K}+\mathrm{Mg})$ and (5) no nutrients (i.e. control plots). Mineral nutrients are added annually to the soil and include $100 \mathrm{~kg} \mathrm{~N} \mathrm{ha}^{-1}$ in the form of ammonium nitrate $\left(\mathrm{NH}_{4} \mathrm{NO}_{3}\right), 35 \mathrm{~kg} \mathrm{P} \mathrm{ha}^{-1}$ in the form of triple superphosphate $\left(\mathrm{Ca}\left(\mathrm{H}_{2} \mathrm{PO}_{4}\right)_{2}\right), 225 \mathrm{~kg} \mathrm{~K} \mathrm{ha}^{-1}$ in the form of muriate of potash $\left(\mathrm{KCl}, \mathrm{K}: 61 \% \mathrm{~K}_{2} \mathrm{O}, \mathrm{Cl}: 46 \%\right)$ and $11 \mathrm{~kg} \mathrm{Mg} \mathrm{ha}^{-1}$ in the form of Epsom salts $\left(\mathrm{MgSO}_{4}\right)$.

\section{Plant Belowground Sampling and Analyses}

In May 2014, a $2.5 \mathrm{~cm}$ diameter soil corer was used to sample soils to a depth of $20 \mathrm{~cm}$ from five random locations within each of the 80 experimental plots included in our study. The five soil samples were homogenised and washed over a $2 \mathrm{~mm}$ size sieve with water to remove soil. Washed roots were oven-dried for 3 days at $60^{\circ} \mathrm{C}$ until they reached constant mass. Once dried, root samples were weighed to estimate total root mass (grams of dry roots per $\mathrm{m}^{2}$ ). A root subsample from each plot was ground to powder and analysed for total root $\mathrm{C}$ and $\mathrm{N}$ content following standard methods on a 1500 NA Carlo-Erba element analyser (Elan Tech, Lakewood, NJ, USA). Dry-root sub-samples were air-dried, ball milled to pass a 150 
$\mu \mathrm{m}$ sieve and then processed for the determination of total $\mathrm{P}$ with the sodium hydroxide $(\mathrm{NaOH})$ fusion method described by Smith and Bain (1982). A final root subsample was stored at $20^{\circ} \mathrm{C}$ for use in a root decomposition experiment (see below).

\section{Soil Sampling and Analysis}

A $2.5 \mathrm{~cm}$ diameter soil core $(0-20 \mathrm{~cm}$ depth) was extracted in May 2014 from four random locations within each of the 80 experimental plots. Soils were sieved through a $2 \mathrm{~mm}$ size mesh and then dried for 3 days at $70^{\circ} \mathrm{C}$. A subsample of the dried soil was analysed for total $\mathrm{C}(\%)$ and $\mathrm{N}(\%)$ content by combustion using a 1500 NA Carlo-Erba element analyser (Elan Tech., Lakewood, NJ, USA). Another subsample was used to estimate extractable phosphorus levels potentially available for plant uptake (i.e. Olsen P analysis) (Olsen et al. 1982). A final soil subsample was used to measure soil $\mathrm{pH}$ by creating a $1: 5$ soil:deionised water suspension.

\section{Soil $\delta^{15} N$ natural abundance}

Because all experimental treatments (i.e. grazing, liming and nutrient fertilization) either directly or indirectly tend to increase (and influence) soil $\mathrm{N}$ availability, we also measured the natural abundance of soil $\delta^{15} \mathrm{~N}$, which might help explaining potential long-term treatment effects on soil N cycling (Robinson 2001; Kleinebecker 2014). Soil subsamples collected in May 2014 from each experimental plot were sieved through a $2 \mathrm{~mm}$ mesh size. An $18 \mathrm{mg}$ of this sieved soil was loaded into each of 80 individual tin capsules, which were then closed and weighed. Each capsule was placed in a well plate, which was then sent to the CHRONO laboratory at Queen's University Belfast, UK for $\delta^{15} \mathrm{~N}$ analyses. Soil samples were then dried and ground to powder and $\delta^{15} \mathrm{~N}$ of soil was determined using a stable isotope mass 
spectrometer (Delta VTM Isotope Ratio Mass Spectrometer - Thermo Fisher Scientific, Waltham, MA USA).

\section{Net Soil Nitrogen Mineralisation Rates}

In June 2014 a $2.5 \mathrm{~cm}$ diameter soil corer was used to extract 3 randomly located soil samples to a depth of $20 \mathrm{~cm}$ in each of the 80 experimental plots. Samples were homogenised and sieved to a $2 \mathrm{~mm}$ mesh size, and stored for 12 hours in a cooler box before be processed in the laboratory. A $20 \mathrm{~g}$ subsample of soil from each plot was suspended in $50 \mathrm{ml}$ of $1 \mathrm{M}$ $\mathrm{KCl}$ before being stored at $4^{\circ} \mathrm{C}$ overnight to allow the soil to settle. Once settled, a sample of the solution was transferred into tubes $(8 \mathrm{ml})$ and analyzed for $\mathrm{NH}_{4}{ }^{+}$and $\mathrm{NO}_{3}{ }^{-}$concentrations. A further $20 \mathrm{~g}$ soil sample from each plot was incubated at room temperature for 30 days. Sufficient water was added to each sample after 2 weeks during the laboratory incubation to keep moisture constant. The same $\mathrm{KCl}$ extraction was then repeated after the 30 dayincubation period and final concentrations of $\mathrm{NH}_{4}{ }^{+}$and $\mathrm{NO}_{3}{ }^{-}$were measured. Soil net $\mathrm{N}$ mineralization rates were calculated by subtracting initial from final $\mathrm{NH}_{4}{ }^{+}$and $\mathrm{NO}_{3}{ }^{-}$ concentrations (i.e. $\mathrm{N}$ mineralization rates were expressed per gram of soil).

\section{Root Decomposition Experiment}

We followed the protocol of Orwin et al. (2010) to estimate potential rates of root decomposition in a controlled laboratory incubation. A subsample of sieved soil (i.e. $31.05 \mathrm{~g}$ of soil) was first added to each of 160 petri dishes ( $90 \mathrm{~mm}$ diameter) (2 petri dishes for each of the 80 experimental plots). Within each petri dish a $1 \mathrm{~mm}$ mesh size disc was placed on top of the soil, covering the entire surface area. Then $0.3 \pm 0.05$ grams of dried roots were placed on the fine mesh in each petri dish before being left to decompose in the dark at an ambient temperature of $25^{\circ} \mathrm{C}$ for 3 months. To test whether root decomposition might 
respond more to (1) changes in local soil conditions under each experimental treatment or more to (2) changes in specific 'root properties' (i.e. root chemistry), we set up two parallel decomposition trials. In the first trial (including 80 petri dishes) a mixture of 'native' roots (i.e. $0.3 \pm 0.05 \mathrm{~g}$ of dried root mass) from each plot (roots collected in May 2014) was decomposed in soils collected from the same plots (i.e. local roots decomposing on local soils). In the second trial we decomposed the roots of a 'non-native' plant species of Nash's Field, namely marram grass (Ammophila arenaria, which was collected in sand dune systems located along the north coast of Northern Ireland) under each of the same 80 local soil conditions used in the first trial (i.e. non-native 'control' roots decomposing on local soils). Roots were dried at $65^{\circ} \mathrm{C}$ for 7 days and a subsample was immediately ground and analysed for total $\mathrm{C}, \mathrm{N}$ and $\mathrm{P}$ content. A sub-sample of the remaining dry roots (i.e. $0.3 \pm 0.05 \mathrm{~g}$ ) was then added to each of the 160 (i.e. 80 'control' marram grass and 80 'local' plant root mixtures) petri dishes (roots $<2 \mathrm{~mm}$ diameter). All petri dishes were sealed (with the lid removed) using $75 \%$ duct tape and $25 \%$ parafilm, before being left in a dark room at an ambient temperature of $25^{\circ} \mathrm{C}$ between $26^{\text {th }}$ June and $30^{\text {th }}$ September 2014 . Water was added to the petri dishes every two weeks to maintain an assumed soil moisture capacity of $9 \%$ by weight (Fornara et al. 2009) during the 3 months of the root incubation period. At the end of the incubation period roots were removed, dried for 7 days at $65^{\circ} \mathrm{C}$, and weighed. Final root mass was compared to initial root mass to estimate the root mass loss (\%) during the experiment. Dried root samples were then ground and analysed for total C, N and P (\%).

\section{Assessment of Mycorrhizal Infection}

In July 2014 soil cores ( $2.5 \mathrm{~cm}$ diameter) were collected to a depth of $20 \mathrm{~cm}$ from 3 random locations within each of the 80 plots included in our study. Root samples were washed over a $2 \mathrm{~mm}$ mesh size and assessed for Arbuscular Mycorrhizal Fungi (AMF) colonisation using an 
adapted version of the protocol developed by Vierheilig et al. (1998). Roots were cut into several $1 \mathrm{~cm}$-long fragments and a random number of root fragments per plot were placed in a labelled cassette. A $90^{\circ} \mathrm{C}$ water bath was used to boil the cassettes in $10 \% \mathrm{KOH}$ solution. After boiling for 10 minutes $\mathrm{KOH}$ solution was poured off and the cassettes were rinsed three times with tap water. Acetic acid was added until it covered all the cassettes and then poured off almost immediately and a $10 \%$ ink solution was finally added. The cassettes were boiled in the ink solution for 5 minutes, then the ink solution was poured off and the cassettes were rinsed 3 more times with tap water before being added to lactoglycerol and left to destain overnight. Roots were mounted in lactoglycerol on labelled microscope slides, running parallel to each other, before being analysed using an Olympus BH2 microscope. Each slide was analysed at magnification x 400 and a crosshair was placed in the eyepiece. An adaptation of the protocol developed by McGonigle et al. (1990) was used for the identification of AMF structures present in the roots, namely hyphae, arbuscules and vesicles were identified and recorded. A total of 100 stops was the aim per slide and a tally of structures that intersected with the crosshair was taken per stop.

\section{Data Analysis}

We used a mixed effects ANOVA model where the four blocks were included as random factors and the experimental treatments (i.e. insecticide, grazing, liming and nutrient applications) represented our (fixed-effect) predictor variables (Appendix S1: Fig. S1). Since the pesticide treatment did not account significantly for variation in any of our response variables, we then produced simpler models, which included only grazing, liming and nutrient as fixed effects. Grazing, liming and nutrient fertilisation treatments are nested within each other and then replicated across four randomly located larger plots (i.e. blocks). 
We tested for potential effects of grazing, liming and nutrient applications (and their interactions) on multiple soil and plant belowground parameters (e.g. total root biomass, root mass decomposability, nutrient accumulation indexes, AMF colonisation etc.). When necessary values were square root transformed to improve normal distribution of residuals. Restricted Maximum Likelihood (REML) method was used to produce final models, which were checked to ensure they conformed to modelling assumptions. Significant differences between factor levels were tested using post-hoc Tukey tests. We also performed simple and multiple regression analyses to identify potential relationships between plant and soil variables, with particular focus on the correlation these variables with soil $\mathrm{pH}$.

We calculated the percent root mass loss as an indicator of root decomposability using the following formula:

$\left(1-\frac{\text { final root mass }}{\text { initial root mass }}\right) \times 100$

We calculated the Nutrient Accumulation Index (NAI) as an index of nutrient dynamics in decomposing root material (Fornara et al. 2009). We distinguished between NAI (for Nitrogen) and PAI (for Phosphorus). Thus, NAI or PAI is equal to:

$$
\frac{W_{t} \times X_{t}}{W_{o} \times X_{o}}
$$

Where $\mathrm{W}_{\mathrm{t}}=$ root dry mass remaining at time $\mathrm{t}, \mathrm{W}_{\mathrm{o}}=$ initial root dry mass, $\mathrm{X}_{\mathrm{t}}=$ root nutrient concentration at time $t, X_{o}=$ initial root nutrient concentration. We assumed that NAI $=1$ would suggest no changes in mass balance for nutrient $\mathrm{X}$ (either $\mathrm{N}$ or P), NAI < 1 would suggest net mineralization of nutrient $\mathrm{X}$, and NAI > 1 would suggest net immobilization of nutrient $X$.

To estimate the degree of AMF colonisation of plant roots we first counted AMF structures (arbuscules, hyphae and vesicles) present on between 14 and 25 root fragments on each microscope slide. We then calculated the proportion of each structure as: 
$\frac{\text { Count of structure per slide }}{\text { Total number of stops per slide }}$ X 100

Total AMF colonisation per slide was estimated by adding the proportion of all structures together (see McGonigle et al. 1990), however, the relative abundance of arbuscules per slide was used in our data analysis due to their presence giving a better indication of mutualistic functioning (Johnson et al. 2003).

\section{Results}

\section{Total root biomass}

We found that grazing did not have any significant effect on total root biomass $\left(\mathrm{F}_{1,60}=0.7 ; \mathrm{P}\right.$ $=0.35$; Fig. 1a), while liming was associated with a significant decrease in root mass $\left(F_{1,60}\right.$ $=15.9 ; \mathrm{P}=0.0002 ;$ Fig. $1 \mathrm{~b}$ ). Total root mass in limed plots was $30 \%$ lower than in un-limed plots. Nutrient additions also had a significant negative effect on total root mass $\left(\mathrm{F}_{1,60}=3.1 ; \mathrm{P}\right.$ $=0.016$ ), which was mainly determined by root mass decreases associated with the All (i.e. NPKMg; Tukey's posthoc test, $\mathrm{P}<0.05)$ nutrient treatment (Fig. 1c).

\section{Root mass decomposition}

Grazing did not affect root mass loss $(\%)$ of either native (from Nash's Field) $\left(\mathrm{F}_{1,60}=0.02, \mathrm{P}\right.$ $=0.88)$ or control (marram grass) roots $\left(F_{1,60}=0.37 ; \mathrm{P}=0.55 ;\right.$ Fig. $\left.2 \mathrm{a}\right)$. The addition of lime significantly increased root mass loss of both control $(+8 \%$ for the marram grass $)\left(F_{1,60}=18.2\right.$, $\mathrm{P}<0.0001)$ and native root species $(+4 \%)\left(\mathrm{F}_{1,58}=5.84 ; \mathrm{P}=0.02\right.$; Fig. 2b). Nutrient additions did not have any significant effect on root mass loss $(\%)$ of either native plant species (from Nash's Field) $\left(\mathrm{F}_{4,60}=0.34, \mathrm{P}=0.85\right)$ or the (non-native)-control marram grass $\left(\mathrm{F}_{4,60}=0.99, \mathrm{P}\right.$ $=0.42$; Fig. 2c). 


\section{Root nutrient accumulation indexes}

Grazing did not affect the nitrogen accumulation index (NAI) of native $\left(\mathrm{F}_{1,60}=0.55 ; \mathrm{P}=\right.$ $0.46)$ or control roots $\left(F_{1,60}=0.30, P=0.59\right.$; Fig. 3a). Also, grazing did not affect the Phosphorus Accumulation Index $(\mathrm{PAI})$ of native $\left(\mathrm{F}_{1,60}=0.45, \mathrm{P}=0.51\right)$ or control roots $\left(\mathrm{F}_{1,60}\right.$ $=0.030, P=0.86 ;$ Fig. $4 \mathrm{a})$. The addition of agricultural lime caused a significant decrease in NAI of control $\left(\mathrm{F}_{1,60}=4.8, \mathrm{P}=0.03\right)$ and native roots $\left(\mathrm{F}_{1,59}=5.72 ; \mathrm{P}=0.02 ;\right.$ Fig. 3b $)$. Liming did not affect PAI of native $\left(\mathrm{F}_{1,60}=0.09 ; \mathrm{P}=0.76\right)$ or control roots $\left(\mathrm{F}_{1,60}=3.88 ; \mathrm{P}=0.05\right.$; Fig. 4b), despite the trend observed suggesting a negative effect of liming.

Nutrient addition did not affect NAI of either native $\left(\mathrm{F}_{4,60}=2.26 ; \mathrm{P}=0.07\right)$ or control roots $\left(\mathrm{F}_{4,60}=0.73, \mathrm{P}=0.58\right.$; Fig. $\left.3 \mathrm{c}\right)$. PAI of native roots was not significantly affected by nutrient addition $\left(\mathrm{F}_{4,60}=0.51 ; \mathrm{P}=0.73\right.$; Fig. $\left.4 \mathrm{c}\right)$, while PAI of control roots was $\left(\mathrm{F}_{4,60}=8.57\right.$; $\mathrm{P}<0.0001)$.

\section{Root AMF colonisation (\%)}

We found no significant effects of grazing on total AMF colonisation (\%) of plant roots in the Nash's Field $\left(\mathrm{F}_{1,60}=3.15, \mathrm{P}=0.15\right.$; Fig. 5a; Appendix S1: Table S1), whereas the addition of lime caused a significant increase ( $+22 \%$ compared to unlimed soils) in total AMF colonization $(\mathrm{P}=0.001$; Fig. 5b; Appendix S1: Table S1). We also found that nutrient additions caused significant changes $(\mathrm{P}=0.003)$ in total AMF colonisation, whereby $\mathrm{N}$-only additions were associated with greater AMF abundance whereas the addition of multiple nutrients (i.e. NPKMg or NPMg treatments) was related to lower AMF colonisation (Fig. 5c; Appendix S1: Table S1). Grazing did not significantly affect other AMF structures while the addition of agricultural lime and nutrients influenced arbuscule and hyphae abundance but not vesicule abundance (Appendix S1: Table S1). 


\section{Soil pH and belowground properties}

Soil $\delta^{15} \mathrm{~N}$ natural abundance was not significantly affected by grazing or nutrient additions but it was significantly negatively affected by repeated liming applications $\left(\mathrm{F}_{1,60}=13.5, \mathrm{P}<\right.$ 0.0001). Liming also increased soil nitrate levels (Appendix S1: Fig. S2) and Nitrogen Use Efficiency (NUE; Appendix S1: Fig. S3). NUE was calculated as the ratio of plant yields (i.e. total aboveground plant biomass; $\left.\mathrm{g} \mathrm{m}^{-2}\right)$ and total $\mathrm{N}$ uptake by the plant community $\left(\mathrm{g} \mathrm{N} \mathrm{m}^{-2}\right)$.

We found that most soil parameters were significantly affected by the liming treatment and that the liming effect was due to strong liming-positive effects $\left(\mathrm{F}_{1,79}=532\right.$, $\mathrm{P}<0.0001$ ) on soil pH (see also Appendix S1: Fig. S4). For example, soil pH was significantly negatively related to total root mass $\left(\mathrm{F}_{1,79}=7.4, \mathrm{P}=0.008\right.$; Fig. $\left.6 \mathrm{a}\right)$, total AMF (\%) colonisation $\left(\mathrm{F}_{1,79}=12, \mathrm{P}=0.001\right), \mathrm{NAI}$ of control roots $\left(\mathrm{F}_{1,79}=4.6, \mathrm{P}=0.03\right)$ and to the decomposition of both native (Fig. 6b) and control roots (Fig. 6c). Soil pH was significantly positively related to soil $\mathrm{NO}_{3}$ concentrations $\left(\mathrm{F}_{1,79}=12.2, \mathrm{P}=0.0008\right.$; Fig. $\left.7 \mathrm{a}\right)$ and negatively related to soil $\delta^{15} \mathrm{~N}\left(\mathrm{~F}_{1,79}=20.8, \mathrm{P}<0.0001\right.$; Fig. $\left.7 \mathrm{~b}\right)$. However, multiple regression analyses show that soil $\mathrm{pH}$ and soil $\mathrm{C}$ and $\mathrm{N}$ stocks were not significantly related (Fig. 7c, d).

\section{Discussion}

Overall, our results show how the common practice of agricultural liming (i.e. the addition of $\mathrm{CaCO}_{3}$ to soils) strongly affected total root mass, root decomposition, root AMF colonisation as well as soil $\mathrm{N}$ availability and cycling. Our evidence is that liming effects were mainly driven by liming-induced increases in soil $\mathrm{pH}$, which influenced multiple root and soil parameters more than animal grazing or chronic nutrient fertilisation.

According to our first hypothesis we found that total root mass was significantly reduced by the long-term addition of multiple nutrients (i.e. NPKMg). This result could be associated with the positive effects that repeated fertilizer applications have on soil nutrient 
availability. Increased soil nutrient availability determines shifts in plant resource allocation from belowground to aboveground plant compartments thus causing a reduction in total root mass (Hobbie 1992, Müller et al. 2000, Hobbie et al. 2010, Zeng et al. 2015). Reductions in total root mass were, however, lower under the N-only and P-only treatments (Fig. 1c), possibly because plants still need to invest in 'foraging' root mass to acquire nutrients, which are less available in soils. Contrary to expectations, we did not find any clear evidence that different nutrient fertilisation applications influenced the decomposition of either control or native roots. Our results show that the addition of all nutrients together (i.e. NPKMg treatment) was associated with increases in native root decomposition whereas the N-only treatment was associated with decreases in native root decomposition but both these effects were not statistically significant (Fig. 2c).

Contrary to our second hypothesis we found no significant grazing effects on total root mass. This is despite the expectation that animal grazing would cause a shift in plant resource allocation from belowground to aboveground compartments to replace the photosynthetic tissue removed by herbivores (Holland and Detling 1990). The lack of significant grazing effects on root mass may be related to shifts in plant species composition under repeated herbivore pressure whereby unpalatable plants are able to maintain their root systems while palatable plants reallocate resources to replace lost aboveground biomass (Schuster 1964). In these grasslands, for example, it was shown that Cirsium arvense (a perennial broadleaf plant species with extensive root systems) greatly benefits from animal grazing mainly because of competitive release from other plant species, which are selectively removed by grazers (Edwards et al. 2000). Net grazing effects on plant belowground mass will ultimately depend on how grazer 'identity' (i.e. rabbits vs. ungulates vs. arthropods) interacts with resistance/resilient traits of dominant plant species to influence soil nutrient availability.

This article is protected by copyright. All rights reserved. 
According to our third hypothesis, we found that root AMF colonisation was significantly lower under chronic multi-nutrient applications (i.e. NPKMg and NPMg), which increased soil nutrient availability including inorganic forms of P. As opposite, AMF abundance was highest under the $\mathrm{N}$-only treatment, a finding, which may further confirm the key role of AMF in P acquisition (Wang et al. 1993, Guo et al. 2012). In fact, it is likely that long-term N-only fertilized soils have become 'P-limited' with relatively high soil N:P ratios (see Appendix S1: Fig. S5) a N-to-P stoichiometric imbalance, which has likely promoted AMF colonization of these roots. AMF colonisation was not significantly influenced by grazing despite previous findings showing that $\mathrm{AMF}$ increases colonisation under grazing (Jansa et al. 2006, Wearn \& Gange 2007).

According to our fourth hypothesis we found that liming had strong positive effects on soil $\mathrm{N}$ availability (e.g. soil $\mathrm{NO}_{3}$ levels) and on soil $\mathrm{N}$ cycling and that liming-induced increases in soil pH significantly influenced both belowground and aboveground compartments. Increases in soil $\mathrm{pH}$ have previously been shown to enhance soil microbial activity and soil N availability (Van Aarle et al. 2002, Kemmitt et al. 2006, Rousk et al. 2011), with significant implications for plant $\mathrm{N}$ uptake. For example, we suggest that decreases in soil $\delta^{15} \mathrm{~N}$ natural abundance under increasing soil $\mathrm{pH}$ values (Fig. 7b), bring evidence of more efficient $\mathrm{N}$ uptake by plants in limed soils. This is supported by our finding that Nitrogen Use Efficiency (NUE) in limed plant communities was higher than in un-limed plants (Appendix S1: Fig. S3). These results also confirm those from a recent study (Kleinebecker et al. 2014), which show how soil $\delta^{15} \mathrm{~N}$ signals decreased under greater plant species diversity because of a more efficient use of $\mathrm{N}$ in species-rich grassland communities. Thus both increased soil nitrate levels and more efficient plant $\mathrm{N}$ uptake may explain the reduced need for plants to invest in large root systems in repeatedly limed soils (Fig. 1b). It is known that agricultural liming tends to improve soil cation exchange capacity, ultimately 
increasing aboveground productivity (Johnson et al. 2005; Fornara et al. 2011) rather than root productivity. Our results also show that liming was associated with higher root decomposition, which could be driven by liming-induced increases in nutrient availability and cycling (Rangel-Castro et al. 2005, Mijangos et al. 2010, Wachendorf 2015). Our evidence is that liming contributed to increase the mineralisation of $\mathrm{N}$ in decomposing root material (Fig. 3a; NAI decreased under lime addition), suggesting that microbes could satisfy their metabolic $\mathrm{N}$ requirements faster in limed soils than in un-limed soils. Liming, however, did not significantly influence changes in P mineralisation-immobilisation in root decomposing material (Fig. 4a), which was significantly influenced by nutrient fertilisation (at least in the control root samples). Control roots decomposing on soils conditioned by the N-only treatment showed a trend toward higher P mineralisation (i.e. low PAI, Fig. 4c) perhaps due to $\mathrm{P}$ limitation compared to $\mathrm{N}$ in these soils. We found, however, that liming was associated with increases in AMF colonisation, and this is possibly due to increased $\mathrm{P}$ immobilisation in limed soils, which could lead to lower $\mathrm{P}$ availability for plant uptake. Higher soil $\mathrm{pH}$ values are usually associated with reduced $\mathrm{P}$ availability in soils due to $\mathrm{P}$ binding with the calcium (Ca) component of lime to form phosphate compounds (Aerts et al. 2003, Olsson et al. 2009, Saarsalmi et al. 2011).

Despite our expectation that grazing would enhance nutrient cycling and hence decrease NAI, our results do not confirm this and differ from previous studies which found $\mathrm{N}$ mineralisation-immobilisation dynamics to be directly affected by grazing (Shariff et al. 1994, McNaughton et al. 1998, Coetsee et al. 2010). It could be that grazing interactions with nutrient fertilisation and liming have reduced net grazing effects on soil nutrient cycling. A recent study from natural tundra ecosystems show how nutrient fertilisation increased soil $\mathrm{N}$ availability in ungrazed rather than grazed plots, and how liming could partly negate nutrient fertilisation effects on soil $\mathrm{N}$ availability (Stark et al. 2012). 
Based on positive correlations between root decomposition and soil $\mathrm{pH}$ we would have expected soil $\mathrm{C}$ and $\mathrm{N}$ pools decrease in limed soils. However, we did not find this evidence in our study, where limed and unlimed plots had similar C (\%) content and similar soil C stocks. Previous studies also found weak correlations between soil $\mathrm{pH}$ and soil $\mathrm{C}$ and N stocks (Kemmitt et al. 2006), and this could be related to the key role of microbial communities and their activities. Recent studies clearly show positive effects of liming on soil C stocks across different ecosystems (Fornara et al. 2011, Melvin et al. 2013), while findings from a review study (Paradelo et al. 2015) suggest that liming can cause both increases and decreases in soil C stocks. Liming-induced increases in the activity of microbes and fauna within the soil would increase the transformation of organic matter via decomposition and mineralisation thus increasing $\mathrm{C}$ losses from soils. On the other hand, liming induced changes in soil structure (as $\mathrm{Ca}$ in lime binds with soil ions) would lead to stabilization of soil macro-aggregates and thus to higher soil $\mathrm{C}$ accumulation (Kunhikrishnan et al. 2016). It could also be that higher microbial activities in limed soils will contribute to increase microbial waste and thus $\mathrm{C}$ detritus, which is incorporated and stabilized into smaller soil organo-mineral fractions (Fornara et al. 2011).

\section{Conclusion}

Our results bring evidence of how liming applications can strongly influence multiple soil and plant properties (and traits) including soil $\mathrm{N}$ cycling, total root mass, root decomposability and root AMF colonisation. Liming-induced increase in soil $\mathrm{pH}$ is a key factor explaining these belowground responses, however, changes in soil $\mathrm{pH}$ were not related to changes in soil $\mathrm{C}$ and $\mathrm{N}$ stocks in this permanent grassland. These findings suggest that regular liming applications could contribute to maintaining grass yields while not having detrimental effects on the $\mathrm{C}$ sequestration ability of grassland soils. Moreover, the addition of 
agricultural lime could significantly reduce the need for artificial nutrient fertilizers because of liming positive effects on soil nitrate levels and on root AMF colonization (which improves $\mathrm{P}$ uptake by plants). We suggest that regular liming applications together with reduced artificial nutrient fertilization could contribute to maintaining grass yields without compromising the delivery of other ecosystem services such as soil nutrient cycling and soil C sequestration, thus enhancing the long-term sustainability of managed grasslands.

\section{Acknowledgements}

This study was funded by a DELNI (Northern Ireland) postgraduate studentship and by the Department of Agriculture, Environment \& Rural Affairs (DAERA) of Northern Ireland (UK) - project number 7001 (41499) and project number 15/4/03 (48073).

\section{Contribution:}

J. Heyburn and D. Fornara equally contributed to write the manuscript. All authors significantly contributed to the research study.

\section{Literature Cited}

Aerts, R., H. De Caluwe, and B. Beltman. 2003. Plant community mediated vs. nutritional controls on litter decomposition rates in grasslands. Ecology 84:3198-3208.

Allan, E. and M.J. Crawley. 2011. Contrasting effects of insect and molluscan herbivores on plant diversity in a long-term field experiment. Ecology Letters 14:1246-1253.

Bardgett, R. 2005. The biology of soil: a community and ecosystem approach, Oxford University Press.

Chapin III, F.S.C., P.A. Matson, and P. Vitousek. 2012. Principles of Terrestrial Ecosystem Ecology.

This article is protected by copyright. All rights reserved. 
Chen, H., L. Mommer, J. van Ruijven, H. de Kroon, C. Fischer, A. Gessler, A. Hildebrandt, M. Scherer-Lorenzen, C. Wirth, and A. Weigelt. 2017. Plant species richness negatively affects root decomposition in grasslands. Journal of Ecology 105: 209-218.

Christopher, S.F. and R. Lal. 2007. Nitrogen management affects carbon sequestration in North American cropland soils. Critical Reviews in Plant Sciences, 26:45-64.

Coetsee, C., W. Stock, and J. Craine. 2010. Do grazers alter nitrogen dynamics on grazing lawns in a South African savannah? African Journal of Ecology 49:62-69.

Conant, R.T., K. Paustian, and E.T. Elliott. 2001. Grassland management and converstion into grassland: Effects on soil carbon. Ecological Applications 11:343-355.

Crawley, M.J. 1990. Rabbit Grazing, Plant Competition and Seedling Recruitment in Acid Grassland. Journal of Applied Ecology 27:803-820.

Edwards, G.R. and M.J. Crawley. 1999. Herbivores, seed banks and seedling recruitment in mesic grassland. Journal of Ecology 87:423-435.

Edwards, G. R., G. W. Bourdôt, and M. J. Crawley. 2000. Influence of herbivory, competition and soil fertility on the abundance of Cirsium arvense in acid grassland. Journal of Applied Ecology 37:321-334.

Fornara, D. A., D. Tilman, and S.E. Hobbie. 2009. Linkages between plant functional composition, fine root processes and potential soil $\mathrm{N}$ mineralization rates. Journal of Ecology 97:48-56.

Fornara, D., S. Steinbeiss, N. P. McNamara, G. Gleixner, S. Oakley, P. R. Poulton, Macdonald, A. J. and R. D. Bardgett. 2011. Increases in soil organic carbon sequestration can reduce the global warming potential of long-term liming to permanent grassland. Global Change Biology 17:1925-1934.

Fornara, D. A, L. Banin, and M. J., Crawley. 2013. Multi-nutrient vs. nitrogen-only effects on carbon sequestration in grassland soils. Global Change Biology, 19:3848-3857.

This article is protected by copyright. All rights reserved. 
Fornara, D. A., E-A. Wasson, P. Christie, and C. Watson. 2016. Long-term nutrient fertilization and the carbon balance of permanent grassland: any evidence for sustainable intensification? Biogeosciences 13:4975-4984.

Guo, Y.J., Y. Ni, H. Raman, B. Wilson, G. Ash, A. Wang, and G. Li. 2012. Arbuscular mycorrhizal fungal diversity in perennial pastures; responses to long-term lime application. Plant and Soil 351:389-403.

Hobbie, S.E. 1992. Effects of Plant Species Nutrient Cycling. Trends in Ecology and Evolution 7:336-339.

Hobbie, S.E., J. Oleksyn, D. Eissenstat and P. Reich. 2010. Fine root decomposition rates do not mirror those of leaf litter among temperate tree species. Oecologia, 162:505-513.

Hodge, A., C. D. Campbell, and A. H. Fitter. 2001. An arbuscular mycorrhizal fungus accelerates decomposition and acquires nitrogen directly from organic material. Nature 413:297-9.

Holland, E. A. and Detling, J. K. 1990. Plant Response to Herbivory and Belowground Nitrogen Cycling. Ecology 71:1040-1049.

Holland, J.N., W. Cheng, and D. A. Crossley. 1996. Herbivore-induced changes in plant carbon allocation: assessment of below-ground C fluxes using carbon-14. Oecologia 107:87-94.

Isbell, F., D. Craven, J. Connolly, M. Loreau, B. Schmid, C. Beierkuhnlein, M. Bezemer, C. Bonin, H. Bruelheide, E. de Luca, A. Ebeling, J. Griffin, Q. Guo et al. 2013. Nutrient enrichment, biodiversity loss, and consequent declines in ecosystem productivity. Proceedings of the National Academy of Sciences of the United States of America 110:11911-6.

Jansa, J., A. Wiemken, and E. Frossard. 2006. The effects of agricultural practices on arbuscular mycorrhizal fungi. Geological Society, London 266:89-115.

This article is protected by copyright. All rights reserved. 
Johnson, D., J.R. Leake, and D. J. Read. 2005. Liming and nitrogen fertilization affects phosphatase activities, microbial biomass and mycorrhizal colonisation in upland grassland. Plant and Soil 271:157-164.

Johnson, N., D. Rowland, L. Corkidi, L. Egerton-Warburton, and E. Allen. 2003. Nitrogen enrichment alters mycorrhizal allocation at five mesic to semiarid grasslands. Ecology 84:1895-1908.

Johnson, N.C., G. Wilson, J. Wilson, M. Miller, and M. Bowker. 2015. Mycorrhizal phenotypes and the Law of the Minimum. New Phytologist 205:1473-1484.

Kemmitt, S.J., D. Wright, K. Goulding, and D., Jones. 2006. pH regulation of carbon and nitrogen dynamics in two agricultural soils. Soil Biology and Biochemistry 38:898-911.

Kleinebecker, T., N. Hölzel, D. Prati, B. Schmitt, M. Fischer and V.H. Klaus. 2014. Evidence from the real world: $15 \mathrm{~N}$ natural abundances reveal enhanced nitrogen use at high plant diversity in Central European grasslands. Journal of Ecology 102:456-465.

Kunhikrishnan, A., R. Thangarajan, N. Bolan, Y. Xu, S. Mandal, D. Gleeson, B. Seshadri, M. Zaman, L. Burton, C. Tang, J. Luo, R. Dalal, W. Ding, M. Kirkham, and R. Naidu. 2016. Functional Relationships of Soil Acidification, Liming, and Greenhouse Gas Flux. Advances in Agronomy 139:1-71.

Liu, L., and T. L. Greaver. 2010. A global perspective on belowground carbon dynamics under nitrogen enrichment. Ecology Letters 13:819-828.

Liu, Y., N. Johnson, L. Mao, G. Shi, S. Jiang, X. Ma, G. Du, L. An, and H. Feng. 2015. Phylogenetic structure of arbuscular mycorrhizal community shifts in response to increasing soil fertility. Soil Biology and Biochemistry 89:196-205.

Lu, M., X. Zhou, Y. Luo, Y. Yang, C. Fang, J. Chen, and B. Li. 2011. Minor stimulation of soil carbon storage by nitrogen addition: A meta-analysis. Agriculture, Ecosystems \& Environment 140:234-244.

This article is protected by copyright. All rights reserved. 
McGonigle, T., M. Miller, D. Evans, G. Fairchild, and J. Swan. 1990. A new method which gives an objective measure of colonization of roots by vesicular-arbuscular mycorrhizal fungi. New Phytologist 115:495-501.

McNaughton, S. J., F. F. Banyikwa, and M. M. McNaughton. 1998. Root Biomass and Productivity in a Grazing Ecosystem : the Serengeti. Ecology 79:587-592.

Melvin, A. M., J. W. Lichstein, and C. L. Goodale. 2013. Forest liming increases forest floor carbon and nitrogen stocks in a mixed hardwood forest. Ecological Applications 23:1962-1975.

Mijangos, I., I. Albizu, L. Epelde, I. Amezaga, S. Mendarte, and C. Garbisu. 2010. Effects of liming on soil properties and plant performance of temperate mountainous grasslands. Journal of Environmental Management 91:2066-2074.

Müller, I., B. Schmid, \& J. Weiner. 2000. The effect of nutrient availability on biomass allocation patterns in 27 species of herbaceous plants. Perspectives in Plant Ecology, Evolution and Systematics 3:115-127.

Olsen, S.R., L. E. Sommers, and A. L. Page. 1982. Methods of soil analysis. Part 2. Chemical and microbiological properties of Phosphorus. ASA Monograph 9:403-430.

Olsson, P., L-M. Martensson, and H. Bruun. 2009. Acidification of sandy grasslands consequences for plant diversity. Applied Vegetation Science 12:350-361.

Orwin, K. H., S. Buckland, D. Johnson, B. Turner, S. Smart, S. Oakley, and R. Bardgett. 2010. Linkages of plant traits to soil properties and the functioning of temperate grassland. Journal of Ecology 98:1074-1083.

Paradelo, R., I. Virto, and C. Chenu. 2015. Net effect of liming on soil organic carbon stocks: A review. Agriculture, Ecosystems and Environment 202:98-107

Propster, J. R. and N. C. Johnson. 2015. Uncoupling the effects of phosphorus and precipitation on arbuscular mycorrhizas in the Serengeti. Plant and Soil 388:21-34.

This article is protected by copyright. All rights reserved. 
Rangel-Castro, I., J. Prosser, N. Ostle, C. Scrimgeour, K. Killham, and A. Meharg. 2005.

Flux and turnover of fixed carbon in soil microbial biomass of limed and unlimed plots of an upland grassland ecosystem. Environmental Microbiology 7:544-552.

Riggs, C., S. Hobbie, E. Bach, K. Hofmockel, and C. Kazanski. 2015. Nitrogen addition changes grassland soil organic matter decomposition. Biogeochemistry 125:203-219.

Robinson, D. 2001. d15N as an integrator of the nitrogen cycle. Trends in Ecology \& Evolution 16:153-162.

Rodwell, J. S. 1992. British Plant Communities, Cambridge University Press.

Rousk, J., P. C. Brookes, and E. Bååth. 2011. Fungal and bacterial growth responses to N fertilization and $\mathrm{pH}$ in the 150 year "Park Grass" UK grassland experiment. FEMS Microbiology Ecology 76:89-99.

Saarsalmi, A., P. Tamminen, M. Kukkola, and T. Levula. 2011. Effects of liming on chemical properties of soil, needle nutrients and growth of Scots pine transplants. Forest Ecology and Management 262:278-285.

Schuster, J. L. 1964. Root Development of Native Plants Under Three Grazing Intensities. Ecology 45:63-70.

Silver, W. W. L., and R. K. R. Miya. 2001. Global patterns in root decomposition: comparisons of climate and litter quality effects. Oecologia, 129:407-419.

Smith, B. F. L., and D. C. Bain. 1982. A sodium hydroxide fusion method for the determination of total phosphate in soils. Communications in Soil Science \& Plant Analysis 13:185-190.

Sochorová, L., J. Jansa, E. Verbruggen, M. Hejcman, J. Schellberg, T. Kiers, and N. Johnson. 2016. Long-term agricultural management maximizing hay production can significantly reduce belowground C storage. Agriculture, Ecosystems and Environment 220:104-114.

Solly, E., I. Schöning, S. Boch, E. Kandeler, S. Marhan, B. Michalzik, J. Müller, J.

This article is protected by copyright. All rights reserved. 
Zscheischler, S. Trumbore, and M. Schrumpf. 2014. Factors controlling decomposition rates of fine root litter in temperate forests and grasslands. Plant and Soil 382:203-218.

Soussana, J.-F. F., and G. Lemaire. 2014. Coupling carbon and nitrogen cycles for environmentally sustainable intensification of grasslands and crop-livestock systems. Agriculture, Ecosystems and Environment 190: 9-17.

Stark, S., A. Eskelinen, and M. K. Männistö. 2012. Regulation of Microbial Community Composition and Activity by Soil Nutrient Availability, Soil pH, and Herbivory in the Tundra. Ecosystems 15:18-33.

Van Aarle, I. M., P. A. Olsson, and B. Söderström. 2002. Arbuscular mycorrhizal fungi respond to the substrate $\mathrm{pH}$ of their extraradical mycelium by altered growth and root colonization. New Phytologist 155:173-182.

Vierheilig, H., A. Coughlan, U. Wyss, and Y. Piché. 1998. Ink and Vinegar, a Simple Staining Technique for Arbuscular-Mycorrhizal Fungi. Applied and Environmental Microbiology 64:5004-5007.

Wachendorf, C. 2015. Effects of liming and mineral $\mathrm{N}$ on initial decomposition of soil organic matter and post harvest root residues of poplar. Geoderma 259-260:243-250.

Wang, G., D. Stribley, P. Tinker, and C. Walker. 1993. Effects of pH on arbuscular mycorrhiza I. Field observations on the long-term liming experiments at Rothamsted and Woburn. New Phytologist 124:465-472.

Wearn, J. A., and A. C. Gange. 2007. Above-ground herbivory causes rapid and sustained changes in mycorrhizal colonization of grasses. Oecologia 153:959-71.

Zeng, C., J. Wu, and X. Zhang. 2015. Effects of grazing on above- vs. below-ground biomass allocation of alpine grasslands on the northern tibetan plateau. PLoS ONE 10:1-15.

This article is protected by copyright. All rights reserved. 


\section{Supporting Information}

Additional supporting information may be found in the online version of this article at http://onlinelibrary.wiley.com/doi/10.1002/eap.xxxx/suppinfo

\section{Data Availability}

Data available from the Dryad Digital Repository: http://dx.doi.org/10.5061/dryad.p0s23

Fig. 1. Effects of animal grazing (a), liming (b) and nutrient additions (c) on total root mass. $\mathrm{YES}=+$ treatment; $\mathrm{NO}=-$ treatment. Error bars $(\mathrm{SE})$ indicate variation in root mass between plots that received the same treatment. Different letters indicate a post-hoc difference in means at $\mathrm{p}<0.05, \mathrm{NS}=$ Not significant; $\mathrm{p}\rangle=0.05$.

Fig. 2. Effects of grazing (a), liming (b) and nutrient additions (c) on root mass loss (\%) from either 'native' or 'control' roots. 'Native' = mix of dry roots collected from each experimental plot in the Nash's Field. 'Control' = dry roots of a non-native control grass species (i.e. Ammophila arenaria). Error bars (SE) indicate variation in root mass between plots that received the same treatment. Different letters indicate a post-hoc difference in means at $\mathrm{p}<0.05, \mathrm{NS}=$ Not significant $; \mathrm{p}>=0.05$.

Fig. 3. Effects of animal grazing (a), liming (b) and nutrient additions (c) on mean "Nitrogen Accumulation Index" (NAI). Error bars (SE) indicate variation in between plots that received the same treatment. Different letters indicate a significant difference, NS = Not significant.

Fig. 4. Effects of animal grazing (a), liming (b) and nutrient additions (c) on mean "Phosphorus Accumulation Index" (PAI). Error bars (SE) indicate variation in PAI between plots that received the same treatment. Different letters indicate a significant difference, NS = Not significant. 
Fig. 5. Effects of animal grazing (a), liming (b) and nutrient additions (c) on total AMF colonisation expressed as percent of total roots infected. Error bars (SE) indicate variation in AMF colonisation between plots that received the same treatment. Different letters indicate a significant difference, NS $=$ Not significant.

Fig. 6. Relationships between soil pH and multiple root traits, which include total root mass $\left(\mathrm{g} \mathrm{m}^{-2}\right)$, native root mass loss $(\%)$, and control root mass loss $(\%)$. Shaded area refers to $95 \%$ Confidence Intervals.

Fig. 7. Relationships between soil $\mathrm{pH}$ and key soil parameters, which include soil $\mathrm{NO}_{3}{ }^{-}$ concentration $\left(\mathrm{mg} \mathrm{kg}^{-1}\right)$, soil $\delta^{15} \mathrm{~N}$, soil $\mathrm{N}$ and soil $\mathrm{C}$ stocks $\left(\mathrm{t} \mathrm{ha}^{-1}\right)$. Shaded area refers to $95 \%$ Confidence Intervals. 

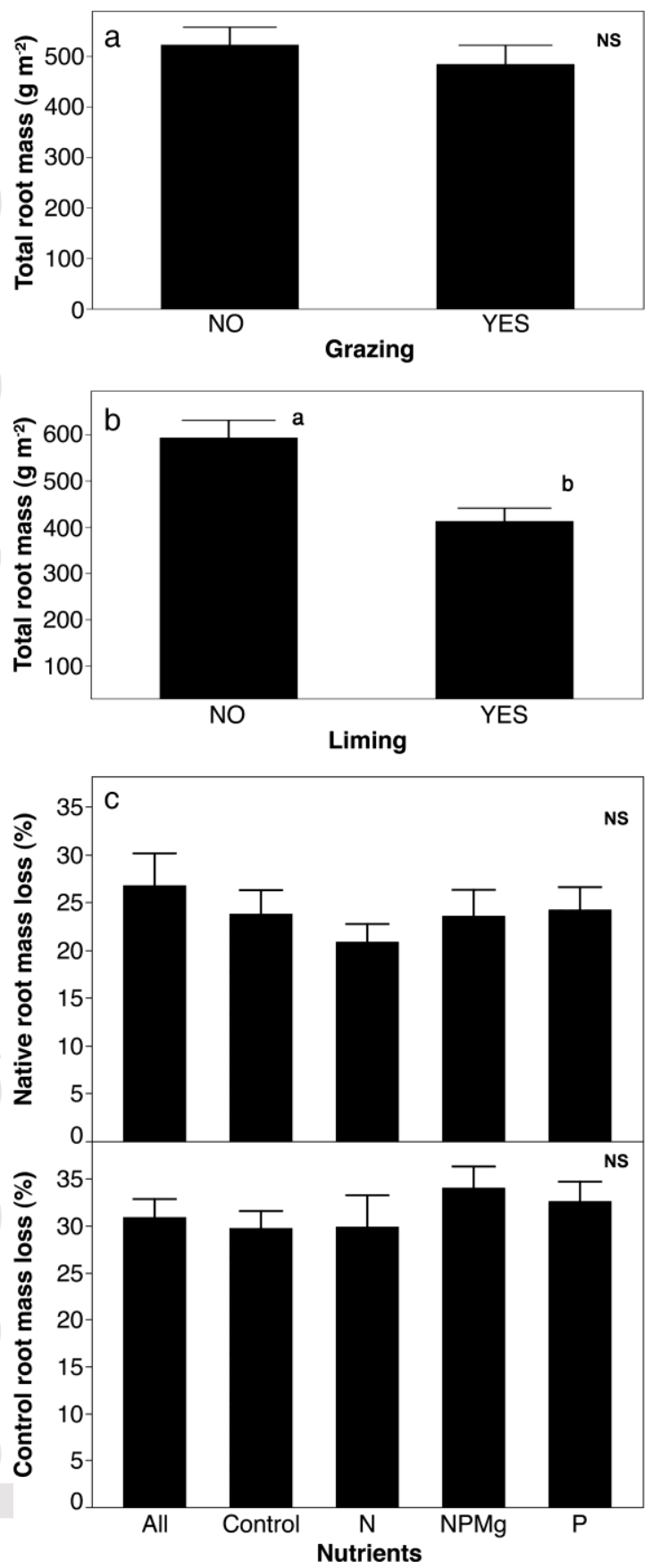

This article is protected by copyright. All rights reserved. 

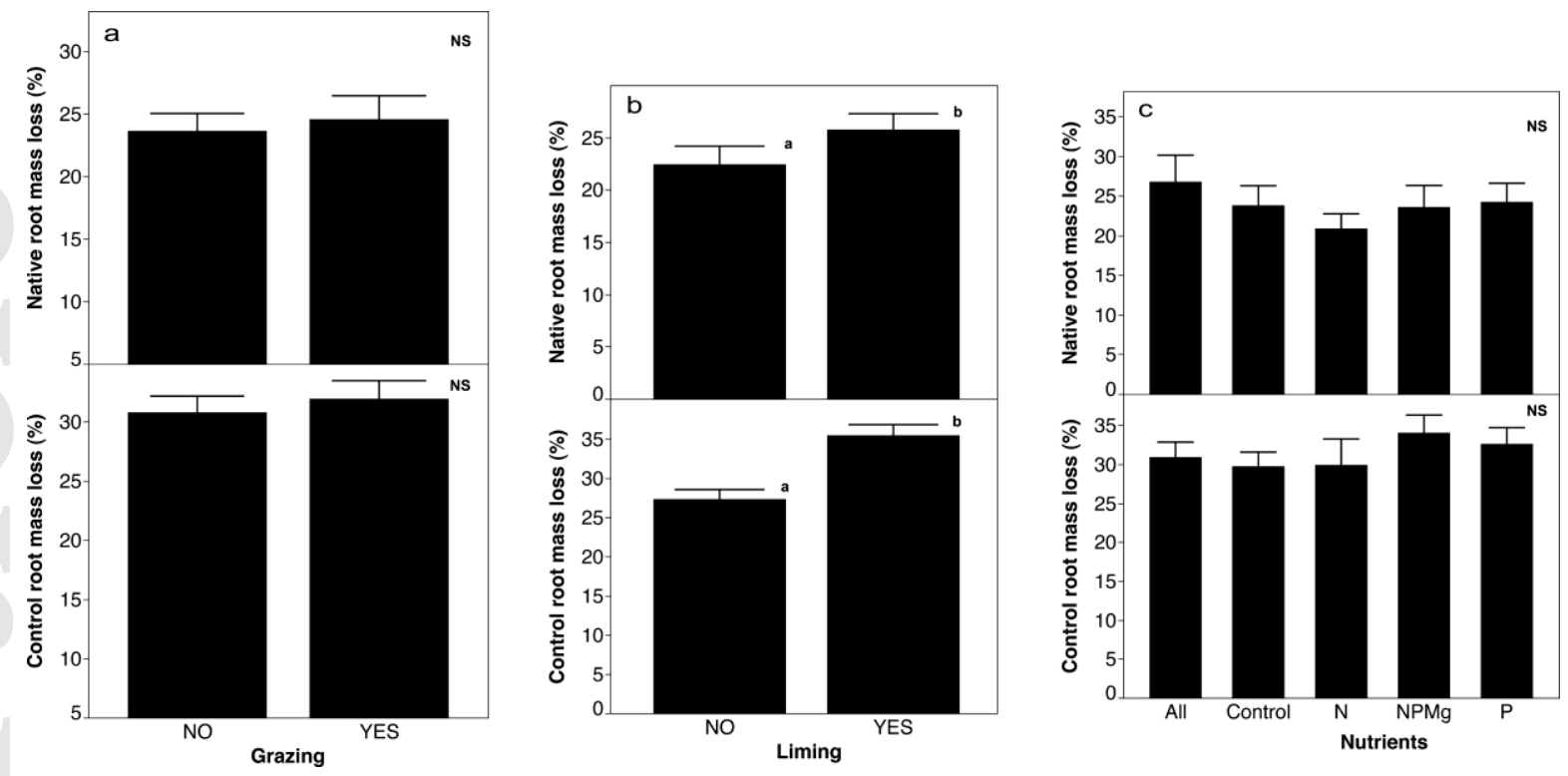

This article is protected by copyright. All rights reserved. 

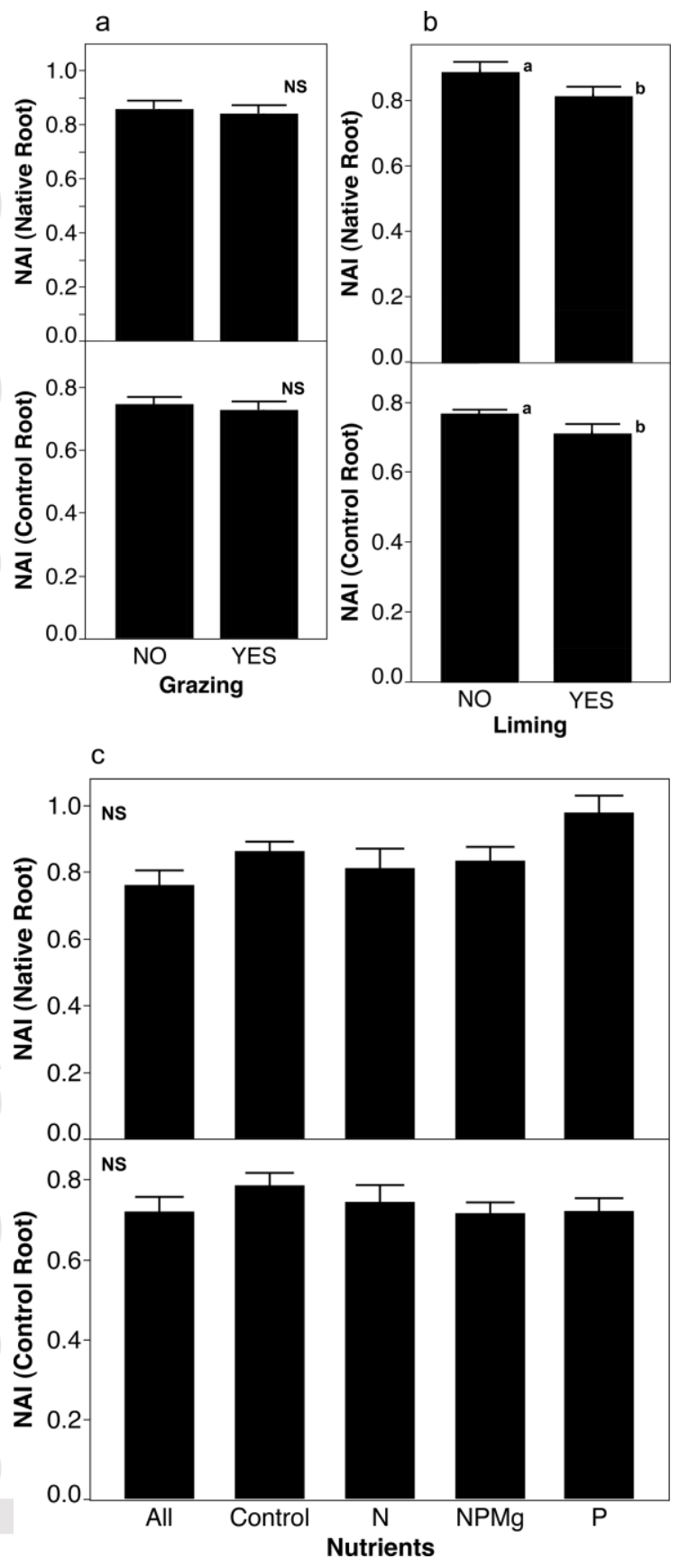

This article is protected by copyright. All rights reserved. 

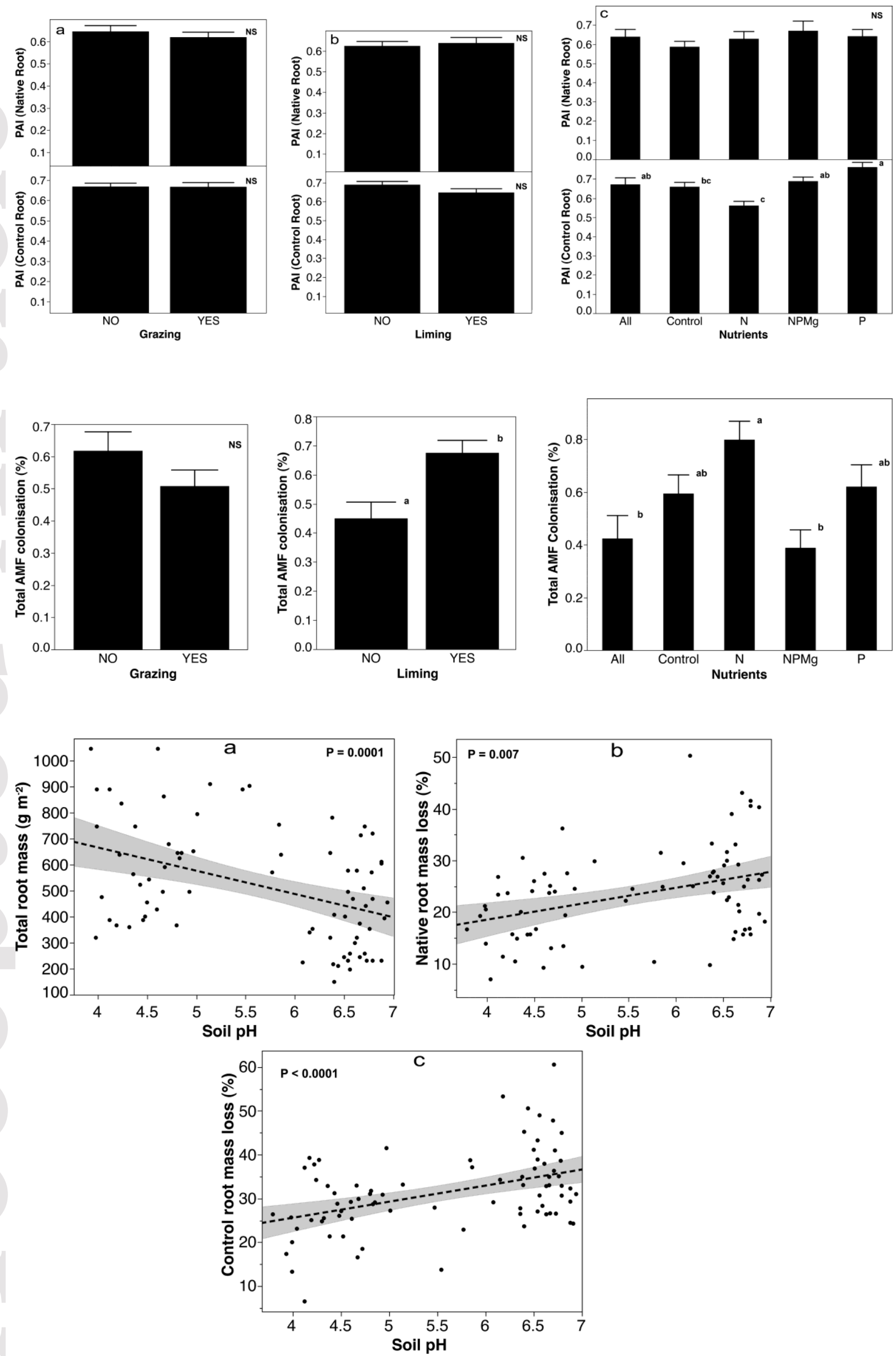

This article is protected by copyright. All rights reserved. 

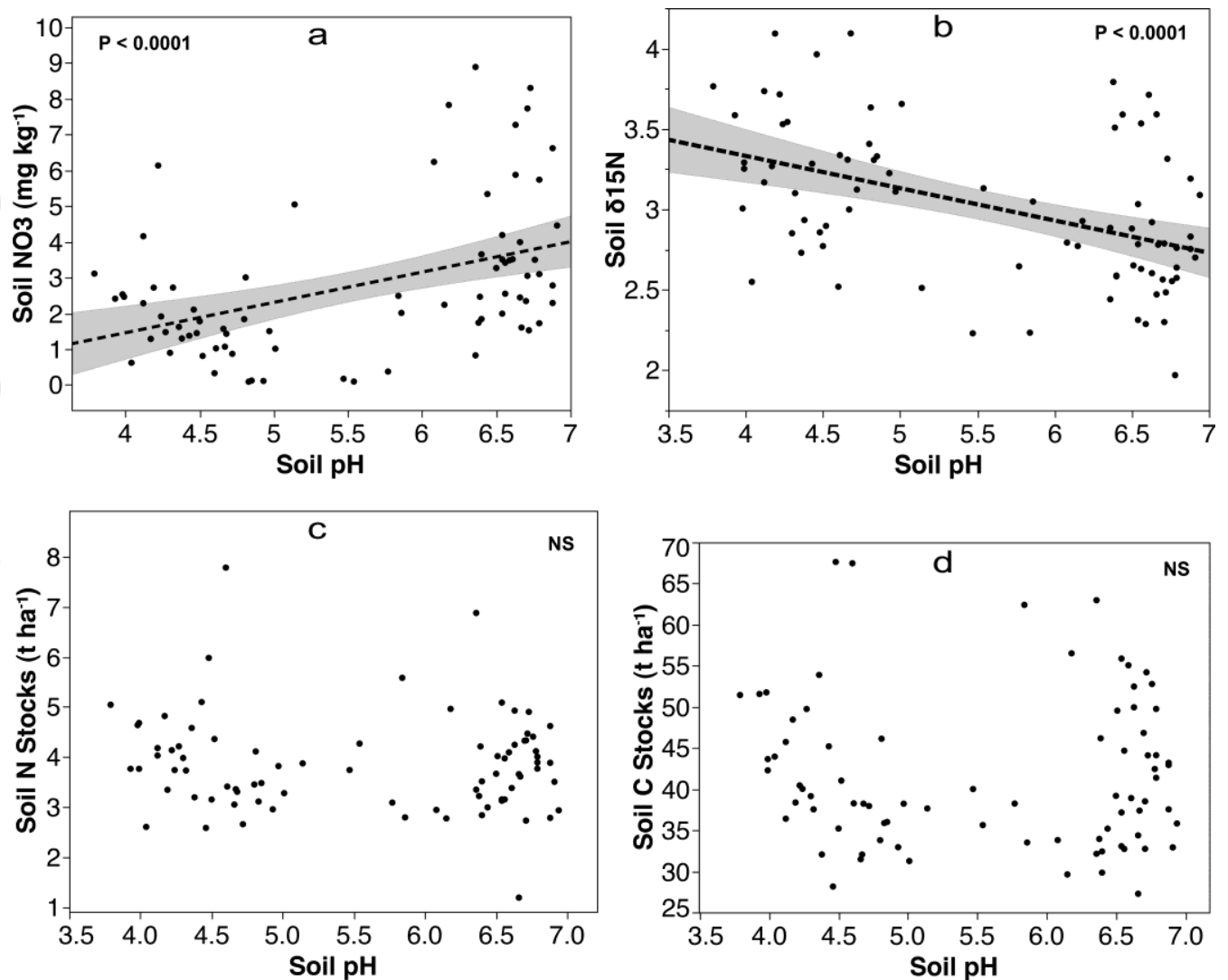

This article is protected by copyright. All rights reserved. 